\title{
INTRACITY PRICE DISPERSION: EVIDENCE FROM ISTANBUL
}

\author{
Asst. Prof. Özlem INANÇ TUNÇER \\ Isik University, FEAS, Istanbul, Turkey, (ozlem.inanc@isikun.edu.tr)
}

\begin{abstract}
The existence of price dispersion is one of the most well known principles of economic theory. Earlier studies concentrated on international purchasing power parity $(P P P)$ deviations. In recent years several studies have examined price dispersion within a nation's borders. In this article the price dispersion among the districts of Istanbul is analyzed by utilizing a data set containing microeconomic price levels from bazaars, convenience stores, and supermarkets. According to results of the study, the prices of homogenous products, except fruit and vegetables, vary less than the prices of differentiated goods as one might expect. Results also indicate that, type of the seller of the product effects price dispersion among the counties of Istanbul.
\end{abstract}

Keywords: Intracity Price Dispersion, Search Cost, Seller Heterogeneity, Istanbul.

\section{ŞEHİRIÇİ FIYYT FARKLILAŞMASI: İSTANBUL ÖRNEĞİ}

\section{ÖZET}

Fiyat farklılaşmasının varliğg iktisat teorisinin en iyi bilinen kaidelerinden biridir. Daha önceki çalışmalar uluslararası satın alma gücü paritesinden sapmaları incelemişlerdir. Son yıllarda birçok çalışmada ise, bir ülkenin sınırları içinde görülen fiyat farklılaşması analiz edilmiştir. Bu çalışmada İstanbul ilçeleri arasındaki fiyat farklılaşması bakkallar, marketler ve pazarlardan toplanan ürün bazında fiyatlar kullanılarak incelenmektedir. Çalışmanın sonuçlarına göre, beklentilere uygun olarak, meyve ve sebze grubu dişındaki homojen malların fiyatları farklılaşmış ürünlerin fiyatlarına göre daha az farklılaşma göstermektedir. Sonuçlar ayrıca satıcılar arasındaki farklılıkların da İstanbul ilçeleri arasındaki fiyat farklılaşmasını etkileyen faktörlerden olduğunu göstermektedir.

Anahtar Kelimeler: Şehiriçi Fiyat Farklılaşması, Araştırma Maliyeti, Satıcı Heterojenliği, Istanbul. 


\section{Introduction}

The existence of price dispersion is one of the most well known principles of economic theory. According to Chen (2004:1257-1286), Law-of-One-Price (LOOP) and Purchasing Power Parity (PPP) studies have data problem since it is almost impossible to select identical (or very close substitute) goods in a group of countries. Therefore, most of these empirical studies utilize time-series technique and analyze change in PPP (relative PPP) instead of PPP itself (absolute PPP). However Crucini et al.(2005: 724-738) make the case that the LOOP and PPP are essentially about the cross-sectional distribution of relative prices rather than the timeseries behavior of changes in these. In recent years, with the availability of product specific micro level data sets, many studies are concentrated on the absolute PPP deviations.

Earlier studies concentrated on international PPP deviations, ${ }^{1}$ but in recent years several studies have examined price dispersion within a nation's border (intranational price dispersion). Two major sources of intranational price dispersion are imperfect information and differences in consumer's search cost. In addition to these, intranational price dispersion may arise because of differences in the sellers' production cost, demand uncertainity due to differences in the repetitiveness of purchases and random exposure to advertising of the consumers, market structure and product characteristics (Lach, 2002:433-444). Ceglowski (2003:373-400) argues that, since there is no international potential barriers to price equalization, in other words no border effect, analysis of the intranational prices can be a natural benchmark against which to evaluate international price behaviour.

According to Rauch (1999:7-35), heterogeneity of products along with the dimensions of both characteristics and quality affect prices. Similarly, Cheung et al.(2001:95-114) argue that, in monopolistic competition with differentiated products, firm's pricing power is determined by the elasticity of demand which depends on the substitutability among varieties within the industry. Therefore, product differentiation creates more dispersed prices and it can be a sign of market power.

In the models of Hotelling (1929:41-57) and Chamberlin(1933), products only differ in their seller's location and differences in seller's geographic location leads to monopolistic competition and, consequently, to price dispersion. Stores may charge different prices for the same homogeneous good. However, even products that are otherwise homogeneous, if they are sold by different sellers, some of this heterogeneity is passed on to the goods. Therefore, these products can be classifed as "differentiated products".

According to Ceglowski (2003:373-400), research on intranational prices has focused primarily on the US but the results are mixed: By using aggregated data for US cities, Culver \& Papell (1999) and Cecchetti et al. (2002: 1081-1099) find extremely slow or no convergence. On the other hand, Parsley \& Wei (1996:1211-1236) and O'Connell \& Wei(2002:21-53) utilize disaggregated data and find evidence of long-run price convergence. Results of Crucini et al.(2004:1-13) indicate that international price dispersion is greater than intranational price dispersion in their data, and distance, which is one of the determinant of international price

1 Please see Bergin \& Glick (2003),Engel et al. (2003), Anderson \& vanWincoop (2004), Atkeson \& Burstein(2004), Crucini et al.(2005), Midrigan(2007) and Crucini \&Yilmazkuday (2014). 
dispersion does not matter for intranational time series dispersion. Chen \& Devereux (2003:213222) study the dispersion of absolute price levels for US cities since 1918 and find strong evidence that there is a convergence over time and the dispersion between the US cities is lower than the one between OECD countries. Results in Crucini et al. (2015:52-66) study indicate that the persistence of the LOOP deviations is rising among the US cities. Parsley \& Wei (2001:87105) use diaggregated prices for Japan and find lower price dispersion for Japan compare to the US. Ceglowski (2003:373-400) analyze intranational price dispersion for Canada. Fan \& Wei (2006:682-697) investigates the price convergence in China. Tsurata (2008:563-584) analyze the determinants of intranational price dispersion by utilizing data from the Japanese gasoline market. Crucini \& Shintani (2008:629-644) find a positive relation between LOOP persistence and the distribution margin by using data from the cities of the US and OECD. Hickey \& Jacks (2011:749-780) utilize a monthly price data from 50 Canadian cities from 1910 to 1950 and analyze the linkages between nominal rigidities and price dispersion. Crucini \& Smith (2014:1-40) study the role of distance and time in explaining price dispersion from 1782 to 1860 for the US cities and Swedish towns. Findings show that commodity-specific fixed effects are an important determinant of the variability in panel. Bergman et al. (2015) investigates intranational price convergence and price stickiness for Denmark. Finally, Elberg (2016:191203) analyze the impact of sticky prices on the volatility and persistence of intranational LOOP deviations by utilizing weekly sampled store level prices from Mexico.

Lach (2002:433-444) uses a unique data set on store-level prices of four homogenous products sold in Israel to study the existence, characteristics and persistence of the dispersion of prices. The departure point of the work is the theoretical literature outcome that rationalize the observed price dispersion as an equilibrium phenomena. Main results show that price dispersion across stores is prevalent even after controlling for observed and unobserved product heterogeneity and differs across products. Lack of full information and some heterogeneity in buyers and/or sellers, which may be passed on to the products, is necessary for price dispersion to exist. In addition, stores move up and down the cross sectional price distribution and, therefore consumers cannot learn about which stores have consistently low prices.

Two major sources of the price dispersion, imperfect information and search costs are closely related with inflation. There is a vast literature that discusses the effect of inflation on price dispersion. Inflation decreases the optimal stock of information held by the consumers, and imperfect decision making affects the dispersion of the prices. For example Benabou(1992) constructs a theoretical model that examines how inflation affects efficiency and output in monopolistically competitive search markets. Simulations of the model indicate three robust results holding across all preference specifications and parameter values. According to first result, although prices are changed more frequently during an inflationary period, as the rate of inflation increases, so does real price dispersion. The second results show that total number of searches also increases as the rate of inflation increases. And finally, third result of this study indicates that there is a negative relation between the rate of inflation and the number of firms in the market (Benabou, 1992:299-329).

Van Hoomissen (1988:1303-1314) considers the question whether observed price differentials reflect perceived differences in quality, service agreements, or location or whether information imperfections can explain this phenomenon and proposes a basis for rejecting the 
"multiple characteristics" hypothesis as the sole determinant of price dispersion. Author uses theoretical argument which links inflation and price distribution. If inflation rate increases, it will decrease the information stock held by agents and create greater price dispersion. By utilizing monthly price data for 13 uniquely defined goods sold in Israel between 1971 and 1984,Van Hoomissen (1988:1303-1314) concludes that price dispersion is positively related to the rate of market price inflation. Since inflation is an unlikely proxy for changes in perceived characteristics, findings support price dispersion theories based on optimally imperfect decision making.

On the other hand, results in Reinsdorf (1994:720-731) indicate negative relation between the price dispersion and inflation. Data used in this study covers US Consumer Price index for nine cities and includes monthly price information for 65 classes of food products from 1980 to 1982. Unlike Van Hoomissen (1988:1303-1314), this study utilizes micro-level data instead of aggregate average prices, however it covers shorter period.

Parsley (1996:323:341), argues that the linkages between relative inflation rates and price dispersion may be masked by the aggregation ofthe data and supports the use of micro data. In this study, four different types of price dispersion is used and the results show that for both across cities and products, higher inflation is associated with greater cross-sectional dispersion of relative prices.

Çağlayan et al. (2008:1187-1208) re-examine the relationship between price dispersion and inflation in Istanbul by using product-specific dataset. The data consist of monthly price observations for individual products sold by individual sellers in Istanbul during the period 1992:10 to 2000:06, and was collected by the Istanbul Chamber of Commerce. Data includes prices for 58 distinct product that are collected from different sources (convenience stores (bakkal), bazaar (pazar) and supermarket) in 15 different counties in Istanbul. Authors find positive and significant relationship in Istanbul for the period covered by data. Similarly, results in Debelle \& Lamont (1997:132-152) indicates that cities in the US that have higher than average inflation also have higher than average price dispersion.

In this article we analyze intracity price dispersion in Istanbul by utilizing a data set containing microeconomic price levels from bazaars, convenience stores, and supermarkets. Outcome of this work may provide better unserstanding of existence, characteristics and peristence of the price dispersion in Istanbul in an inflationary period.

The remainder of this paper is organized as follows. Section 2 discusses motivation, describes the data, and methodology and reports the main results. Section 3 briefly concludes.

\section{Motivation, Data, Methodology and Results}

Price dispersion has different effects on buyers and sellers. For sellers, dispersed prices affects pricing decisions via differential market power; higher price dispersion is a sign for higher market power. For buyers, price dispersion increases the incentive to search and differential search costs creates welfare variation among the individuals (Head \& Kumar, 2005:533-572). 
Literature on price dispersion listed imperfect information and search cost differentials of the consumers as the two major causes of price dispersion. But if data belongs to an inflationary period, the results should be interpreted more carefully since both of these effects are linked with inflation. If inflation rate increases, it will decrease the information stock held by agents and generally create greater price dispersion. Inflation also affects search activities of consumers for the minimum price. However, effect of search cost variations can be seen more clearly when the expected rate of inflation is not too high, since the household have less incentive to search for a cheaper alternative when hyperinflation weakens the purchasing power of money and price dispersion is not their primary focus (Casella \& Feinstein, 1990; Tommasi, 1999; Fershtman et.al., 2003). In addition to this, number of papers that studied the effect of inflation and price dispersion on welfare (e.g., Benabou, 1988, 1992; Diamond, 1993; Tommasi, 1994; Peterson \& Shi, 2002) argue that inflation lowers the purchasing power of money by increasing the average real price, so the level of consumption of the households would decrease by more than it would if they have sufficient information to force prices to be set at if the market was competitive. In other words, price dispersion increases the welfare cost of inflation (Head \& Kumar, 2005:533-572).

Although several papers in the literature find a positive relationship between the inflation and the price dispersion, the effect of inflation on the price dispersion differs with the choice of the model, time period and data. (Caglayan et.al., 2008:1187-1208). So, the relation between these is an empirical issue, and therefore a detailed investigation of the data during an inflationary period would be beneficial to understand the size and the effect of the dispersed prices.

Dataset in this study contains monthly price observations of different consumer goods and services from bazaars, supermarkets and grocery stores (bakkal) in 15 different counties in Istanbul, Dataset is collected by the Istanbul Chamber of Commerce and covers from 1992:10 to 2000:06, when the inflation rate is high at about $80 \%$ per annum. The 15 districts of Istanbul are Aksaray, Bahcelievler, Bakirkoy, Besiktas, Beyoglu, Eminonu, Eyup, Fatih, Kadikoy, Kartal, Kasimpasa, Levent, Pendik, Sariyer, and Sisli. The dataset contains a wide variety of products including basic household items such as bread, milk, yogurt, sugar, coffee, and textile products, durable goods, as well as service items such as rent, hairdresser, taxi fair, restaurant meals. ${ }^{2}$ Grocery category is the largest with 236 different products (37 of which are service items). Bazaar category has price information for 50 products in total, while supermarket category has for 46.

Data has been scrutinized in detail and products with insufficient data points has been excluded. ${ }^{3}$ The remaining dataset comprises 140 products for grocerys, 50 for bazaars, and 34 for supermarkets. Then, a three-digit ISIC (Rev.2) code has been appointed to each product in the dataset. Products in the bazaar, grocery, and supermarket datasets belong to following industry groups are listed in Table 1 to Table 3.

2 Services are not included in this analysis due to the data coding and matching process that is explained in Section 2.

3 The products with price information in 10 districts or more were kept. 
Table 1: Data Collected From Grocery Stores

\begin{tabular}{llc}
\hline ISIC & Industry Definition & Products \\
\hline 31 & Manufacture of food, beverages and tobacco & 73 \\
\hline 32 & Textile, wearing apparel and leather industries & 51 \\
\hline 34 & Manufacture of paper and paper products, printing and publishing & 2 \\
\hline 35 & $\begin{array}{l}\text { Manufacture of chemicals and chemical, petroleum, coal, rubber and } \\
\text { plastic products }\end{array}$ & 8 \\
\hline 38 & Manufacture of fabricated metal products, machinery and equipment & 5 \\
\hline 39 & Other manufacturing industries & 1 \\
\hline
\end{tabular}

Table 2: Data Collected From Supermarkets

\begin{tabular}{llc}
\hline ISIC & Industry Definition & Products \\
\hline 31 & Manufacture of food, beverages and tobacco & 26 \\
\hline 34 & Manufacture of paper and paper products, printing and publishing & 1 \\
\hline 35 & $\begin{array}{l}\text { Manufacture of chemicals and chemical, petroleum, coal, rubber and } \\
\text { plastic products }\end{array}$ & 5 \\
\hline 38 & Manufacture of fabricated metal products, machinery and equipment & 2 \\
\hline
\end{tabular}

Table 3: Data Collected From Bazaars

\begin{tabular}{llc}
\hline ISIC & Industry Definition & Products \\
\hline 31 & Manufacture of food, beverages and tobacco & 50 \\
\hline
\end{tabular}

As it was mentioned above, in the literature, power of sellers over price determination in imperfect markets is also articulated to be a source of price dispersion. Therefore, the products in the data set are classified into three categories as suggested by Rauch (1999:735 ); products traded on an organized exchange, reference priced products ${ }^{4}$, and differentiated products. In order to associate Rauch classification and price data, a standard international trade classification (SITC) code has been appointed to each product. ${ }^{5}$ Accordingly, classifications that involve product characteristics are summarized in Table 4:

4 Rauch (1999) classified these categories as "homogeneous products" since the numbers of commodities traded in organized exchanges are quite limited and possessing a reference price distinguishes homogeneous goods from differentiated goods.

5 Rauch data and information about matching ISIC-SITC codes have been obtained from Haveman's web page www. macalester.edu/econdata/page/haveman 
Table 4: Rauch Classified Price Data

\begin{tabular}{lccc}
\hline Rauch Classification & \multicolumn{3}{c}{ No.of Product } \\
\hline Differentiated products & Grocery stores & Supermarkets & Bazaars \\
\hline a)Products sold in organized exchanges & $\mathbf{7 7}$ & $\mathbf{1 6}$ & $\mathbf{5}$ \\
\hline b) Products with reference price & 10 & 3 & 2 \\
\hline Total homogeneous products & 53 & 15 & 43 \\
\hline
\end{tabular}

In the study, price dispersion is measured by coefficient of variation (COV). Expressed as a percentage, $\mathrm{COV}$ is defined as the ratio of the sample standard deviation to the sample mean and calculated by using the following formula:

$$
C O V=\sigma / \mu * 100
$$

where $\sigma$ represents standard deviation and $\mu$ is the non-zero mean. ${ }^{6} \mathrm{COV}$ is a dimensionless number so it enables to make comparison between data sets with widely different means and/or standard deviations.

Evaluation of the dataset as a whole revealed that there was a significant price dispersion across the districts of Istanbul, in both product and industry levels. In the focus period, coefficient of variation, is measured for 140 products. Salt and giblets have the minimum values with $4.81 \%$ and $4.83 \%$, and maximum values are $36.64 \%$ for slipperies, $35.36 \%$ for socks, and $34.65 \%$ for coat. Morover, COV values for products fluctuate throughout the period. When compared to the first period, 1993, in the last period, 1999, coefficient of variation for 54 out of 140 products diminished (e.g. 69\% for instant soup, $47 \%$ for lentil, and 6\% for green onions), while it increased for the rest of the products. Maximum increase was near 290\% for slippers and peas have the minimum with $0.68 \%$. Average COV of the whole dataset is $15.47 \%$ in 1993 , $15.42 \%$ in $1994,13.48 \%$ in $1995,15.18 \%$ in $1996,14.87 \%$ in $1997,15.14 \%$ in 1998 , and $17.06 \%$ in 1999 . These values can be accepted as a strong indicator of intracity price dispersion in Istanbul.

The literature on the link between price dispersion and price level offers different results. Some studies have found the relationship to be positive, while others have found a negative link (or no link at all). Opponents of the negative relation claim that buyers tend to shop from less expensive locations because search cost-product price ratio of buyers for expensive products is relatively low. Therefore prices converge as the law of demand suggests. Positive relation argument depends on the idea that buyers do not spend much time for the products which are less frequently bought (have less share in the budget), therefore different prices occur. When the link between average prices and coefficient of variation is examined in the entire dataset, it is observed that the relationship is positive in 1993 (28\%) and 1995 (40\%) and negative for the years 1997,1998 and $1999(-40 \%,-42 \%$, and $-38 \%$ respectively). For 1994, the relation is

6 In other words, coefficient of variation indicates the percentage change in standard deviation with respect to mean. A small coefficient of variation means small variation across units in the group, which means that the group is more homogeneously distributed. 
highly statistically insignificant. In the product-level, the ratio of maximum-minimum prices lay between $1.18 \%$ and $6.81 \%$. These values indicate that there are differences in pricing across sellers, especially in some products.

Examination of industry-level data points out that the industries with the largest average coefficient of variation value are "fabricated metal products" coded $381(55.11 \%)$, "textile" coded 321 (54.46\%), whereas "beverages" coded $313(5.37 \%)$ and "other chemicals" coded $352(5.22 \%)$ are the industries which has the smallest values. A small but positive relation is observed between average prices and average coefficient of variation $(21.12 \%)$. As the average price increase in an industry, the difference between maximum and minimum prices also increases.

\section{Figure 1: Industries with Lowest and Highest COV}

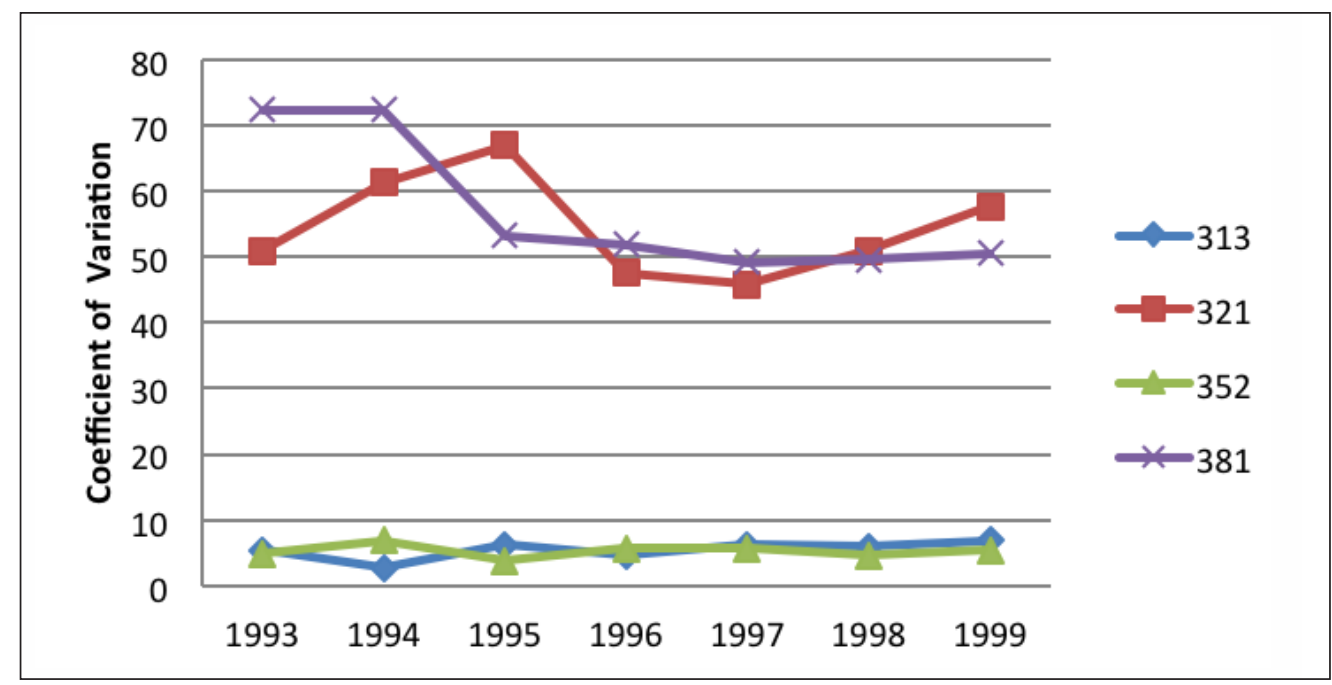

In accordance with the discussion above, product features have also significant role in pricing. There is a strong negative correlation (-42.6\%) between average price and coefficient of variation for differentiated products between 1993 and 1999. The same correlation is found to be $40 \%$ for homogeneous products. When items in the categories are examined, it can be seen that homogeneous product category include mostly food products (such as meat, milk, eggs, vegetables, fruits), which are consumed frequently in daily life, whereas differentiated product category covers various products such as textiles, clothing, cleaners in addition to some food products (chocolate, coffee). According to the findings, it can be articulated that costumers in Istanbul do not search extensively for daily consumption due to the search cost, and as a result of the search undergone for other products, the prices across districts converged to each other.

In analysis above, the prices collected from groceries, bazaars, and supermarkets have been studied concurrently in the same dataset. Since examining price dispersion for different seller groups is one of the research objective of the study, a similar analysis has been conducted within grocery, bazaar, and supermarket categories separately. 


\subsection{Analysis of Price Data Collected from Groceries}

The data collected from groceries is the most detailed part of the ICOC dataset on basis of both product diversity and size. As shown in Table 1, after the organization of the data, there are prices of 140 products.

When prices are examined, it has been seen that Eminonu district had the cheapest prices for most of products in the dataset for the time period. Presence of locations like Spice Bazaar is the reason why this district is cheapest in products such as cheese, olives, and snacks. In 1993, Eminonu district where 79 out of 140 products in the data set were the lowest was followed by Kasimpasa district with 41 products. Eminonu has the lowest price level for almost $40 \%$ of the products between 1994 and 1998. Bakırkoy, Beyoglu, and Bahcelievler in European side and, Kadikoy in Asian side of Istanbul are the districts that had the least number of lowest prices.

In 1993, Sisli district, where nearly half of the products in the dataset were the most inexpensive, left its position to Bakirkoy and Beyoglu in the later years. Kadikoy was the most expensive district in the Asian-side. In the dataset, other two districts in Asian-side, Kartal and Pendik were the districts that had the most expensive prices in the least number of products, while in European-side of the city Sariyer and Kasimpasa had a similar tendency.

Price dispersion across districts has been confirmed by the data collected from groceries. It has been observed that coefficient of variation differs across products. The smallest (average) coefficients of variation are $4.33 \%$ for chicken and $4.81 \%$ for salt. The coefficients of variation measured deploying the entire dataset for these products were $6.36 \%$ and $4.80 \%$ respectively; therefore it can be observed that there were no differences among sellers in determination of, especially, price of salt. Average price dispersion in food products (industry coded 311) has been calculated to be $5.33 \%$. But this value was $34 \%$ when measured using the entire dataset. Dispersion in prices of vegetable and fruits were higher than the industry average. For example, coefficients of dispersion were $10.6 \%$ for apples and oranges, $16.84 \%$ for cherries, $15 \%$ for strawberries and quinces, and $18 \%$ for apricots. The coefficients of dispersion measured using the entire dataset were $22.5 \%$ for apples, $23.26 \%$ for cherries, $19 \%$ for oranges, $22.19 \%$ for strawberries, and $23.65 \%$ for apricots. The differences in values measured using different data levels points out that there are significant differences in prices determined by different groups of sellers (groceries and bazaars). In addition to these, seasonality of the fruits and vegetables products contribute the high level of price dispersion significantly. The values calculated for meat, offal, and cheese were on level with or just less than the industry average.

The largest average coefficients of variation were calculated for textiles coded 321 (16.78\%), clothing coded 322 (20.61\%), leather and leather products coded 323 (12.87\%), and shoes coded $324(14.27 \%)$ all of which are under "textiles, clothing and leather products" industry coded 32 . The average coefficient of variation for the industry coded 32 calculated to be $16.13 \%$. The values measured using the entire dataset were also high for textiles.

Finally, in the time period, calculated coefficients of variation were relatively larger in differentiated products, namely that different grocery stores in districts determined different prices for differentiated products. The impact of the textiles industry was very significant. Average price-coefficient of variation link varies between product categories. The correlation 
is found to be 0.80 for homogeneous products whereas it is -0.78 for differentiated products. The argument on search costs that was discussed for the total dataset can be said to be valid for groceries, too.

\subsection{Analysis of Price Data Collected from Supermarkets}

After organizing the data collected by ICOC from supermarkets, a sample comprising 34 products has been constructed. Compared to groceries, supermarkets have more homogeneous price distribution. There were no products in Bakirkoy and Sisli that had the cheapest price among districts in the time period of the study, while Beyoglu had one only in 1998, and Levent had one in 1998 and 1999. Kartal in Asian-side, and Kasimpasa in European-side of Istanbul are the districts that had the cheapest prices in the most products. Eminonu, where had the cheapest prices for almost half of the products in grocery-level, was in the middle of the list for comparison among supermarkets. On the other hand, Bakirkoy, Beyoglu, and -in the last years of the period- Aksaray stand out as the districts with expensive prices for products in the dataset. Number of products in the Asian-side districts, namely Kadikoy, Kartal, and Pendik, with the most expensive price were much less than those in European-side.

When compared between supermarket-level and grocery-level data, coefficient of variation calculated for 30 common products out of 34 has been found to be higher in supermarkets. Only coefficients of variation for cleaning dust, detergents, margarine, and oil were greater in groceries, but the difference is less than $1 \%$. However, for some products difference between coefficients of variation in supermarkets and groceries is much greater (for example, difference is $18 \%$ for eggs, $6 \%$ for wheat, and $5 \%$ for sausages). On the other hand average grocery prices were higher than supermarket prices for every product. The differences vary between $1 \%$ and $13 \%$.

When supermarkets and bazaars were compared, it has been observed that for 14 products which are all common in both categories, supermarkets have the highest price in the time period of the study. Most of the sellers with the cheapest prices were settled in bazaars. Finally, for supermarkets, contrary to the expectations, price dispersion was not higher than the dispersion for grocery stores. Caglayan et al. (2008) argued that, lower dispersion for grocery stores makes sense since menu costs are likely to be small in those stores. Results of this study indicate that, although the relationship between average price and COV was positive as in the analysis of total dataset and grocery data, calculated value is much smaller $(-23.7 \%$ for differentiated products, and $10.1 \%$ for homogeneous products). However, it must be stressed that products related to textile industry which had a significant impact on grocery level (so on total dataset), are not comprised in supermarket-level data. Therefore, analysis has been repeated and interpreted only for common products. For this sample of the products, price dispersion in grocery store prices is on average less than dispersion in supermarket prices as it was expected.

\subsection{Analysis of Price Data Collected from Bazaars}

The dataset has information from 15 districts at grocery and supermarket level, whereas data is available only for 13 districts at bazaar level; for Levent and Pendik there is no price data. After organizing, the dataset comprises 50 products that is classified under industry coded 
311.35 of them are in vegetable and fruits category. Bazaar level data indicates that distribution of minimum prices is different from that of grocery and supermarkets. As in grocery level, bazaars in Eminonu have the cheapest prices for most of the products. In the Asian-side, Kartal bazaars have the cheapest prices for a large number of products in the beginning of the time period of the study, whereas this feature is lost by the end.

Bakirkoy, Bahcelievler, and Beyoglu stand out as the districts having the highest prices for largest number of products. In the Asian-side, Kartal bazaars had no products with the highest price except for only one in 1993 and four in 1994 while in Kadikoy, there were only four products with the highest price among the bazaars in the time period. In Eminonu, no product was charged with the highest price.

A similar price dispersion pattern to those across groceries and supermarkets has been observed across bazaars. For example, in bazaar dataset, the largest dispersion is observed for apricots with coefficient of variation being $17.56 \%$. The same ratio across groceries has been calculated to be $16.84 \%$. Across the bazaars the coefficients of variation are $7.90 \%$ for oranges ( $10.6 \%$ across groceries), $7.77 \%$ for apples (10.6\% across groceries), and $15.85 \%$ for cherries ( $16.84 \%$ across groceries). The coefficient for more than half of the products has increased between 1993 and 1999.

Bazaars contain a large number of seller within a small area, resulting very low search cost for customers; therefore sellers have very little pricing power on their product. So it is expected that bazaars will have the least amount of price dispersion on average (Caglayan et al., 2008:1187-1208). In our data, when groceries, supermarkets and bazaars are compared (by using the common products sold), bazaars have lower COV. Moreover, it is observed that almost all products are cheaper in bazaars.

\section{Conclusion}

In the analysis above, the descriptive statistics measured indicate that prices across districts in Istanbul were highly dispersed for all of the seller categories. The dispersion is calculated to be over $30 \%$ for some products. The possible factors causing the price dispersion are differences in product characteristics (homogeneous or differentiated, durable vs. nondurable, share in the budget, brand image), differences in seller characteristics (size, discount opportunities, grocery, bazaar, or supermarket distinction as in the dataset), differences in district characteristics (proximity to the center, transportation availabilities, size), and differences in customer characteristics. The search costs are also emphasized as a significant factor since they are mostly affected by the differences among customers. Population structure and income differences can be listed among factors that change search costs. Further analysis will be focused on the development and estimation of the model that will help explaining the causes of the dispersion.

\section{Acknowledgement}

I would like to gratefully acknowledge the financial support from the Turkish Scientific and Technical Research Council (TUBITAK) under grant number 111K095. I also acknowledge the Istanbul Chamber of Commerce (ICOC) for providing the dataset. 


\section{References}

Anderson, E. J., \& vanWincoop, E. (2004). Trade costs. Journal of Economic Literature, 42 (3), 691-751.

Atkeson, A., \& Burstein, A. (2004, November). International relative prices in new ricardian models of international trade. Manuscript, UCLA.

Benabou, R. (1988). Search, price setting and inflation. The Review of Economic Studies, 55 (3), 353-376.

Benabou, R. (1992). Inflation and efficiency in search markets. The Review of Economic Studies, 59 (2), 299-329.

Bergin, R. P., \& Glick, R. (2003). Endogenous nontradability and macroeconomic implications. NBER Working Paper, W9739.

Bergman, M., Heebol, C., \& Hansen, N.L. (2015). Intranational price convergence and price stickiness: Evidence from Denmark. Manuscript.

Caglayan, M., Filiztekin, A., \& Rauh, M.T. (2008). Inflation, price dispersion, and market structure. European Economic Review, 52 (7), 1187-1208.

Casella, A., \& Feinstein, J. (1990). Economic exchange during hyperinflation. Journal of Political Economy, 96, 1-27.

Cecchetti, S., Nelson, M., \& Sonora, R. (2002). Price level convergence among united states cities: Lessons for the European Central Bank. International Economic Review, 43 (4), 1081-1099.

Ceglowski, J. (2003). The law of one price: Intranational evidence for Canada. Canadian Journal of Economics, 36 (2), 373-400.

Chamberlin, E. (1933). The theory of monopolistic competition. Cambridge, Mass: Harvard University Press.

Chen, N. (2004). The behaviour of relative prices in the European Union: A sectoral analysis. European Economic Review, 48 (6), 1257-1286

Chen, LL., \& Devereux, J. (2003). What can US city price data tell us about purchasing power parity?. Journal of International Money and Finance, 22(2), 213-222.

Cheung, Y-W., Chinn, M.D, \& Fujii, E. (2001). Market structure and the persistence of sectoral real exchange rates. International Journal of Finance and Economics, 6 (2), 95-114.

Crucini, M., Telmer, C., \& Zachariadis, M. (2004). Price dispersion: The role of borders, distance, and location. Carnegie Mellon University GSIA Working Paper, 2004-E25.

Crucini, M., Telmer, C., \& Zachariadis, M. (2005). Understanding european real exchange rates, The American Economic Review, 95(3), 724-738.

Crucini, M., \& Shintani, M. (2008). Persistence in law of one price deviations: Evidence from micro-data. Journal of Monetary Economics, 55(3), 629-644.

Crucini, M., Shintani, M., \& Tsuraga, T. (2015). Noisy information, distance, and law of one price dynamics across US cities. Journal of Monetary Economics, 74(September), 5266. 
Crucini, M., \& Smith, G.W. (2014). Geographic barriers to commodity price integration: Evidence from US cities and Swedish towns 1732-1860. NBER Working Paper, 20247.

Crucini, M., \& Yilmazkuday, H. (2014). Understanding long-run price dispersion. Journal of Monetary Economics, 66(September), 226-240.

Culver, S., \& Papell, D. (1999). Panel evidence of purchasing power parity using intranational and international data. Unpublished Manuscript.

Debelle, G., \& Lamont, O. (1997). Relative price variability and inflation: Evidence from US cities. Journal of Political Economy, 105(1), 132-152.

Diamond, P. (1993). Search, sticky prices and inflation. Review of Economic Studies, 60 (January), 53-68.

Elberg, A. (2016). Sticky prices and deviations from the Law of One Price: Evidence from Mexican micro-price data. Journal of International Economics, 98(January), 191-203.

Engel, C., \& Rogers J. H. (1996). How wide is the border?. The American Economic Review, 86(5), 1112-25.

Engel, C., Rogers, J. H., \& Wang, S.Y. (2003). Revisiting the border: An assessment of the Law of One Price using very disaggregated consumer price data. InternationalFinance Discussion Papers, 777.

Fan, S., \& Wei, X. (2006). The law of one price: Evidence from the transitional economy of China. Review of Economics and Statistics, 88(4), 682-697.

Fershtman, C., Fishman, A., \& Simhon, A. (2003). Inflation and efficiency in search economy. International Economic Review, 44, 205-222.

Goldberg, P. K., \& Verboven, F. (2001). The evolution of price dispersion in the European Car Market. Review of Economic Studies, 4, 811-848

Head, A., \& Kumar, A. (2005). Price dispersion, inflation and welfare. International Economic Review, 46(2), 533-572.

Hickey, R. D., \& Jacks, D. S. (2011). Nominal rigidities and retail price dispersion in Canada over the twentieth century. Canadian Journal of Economics, 44(3), 749-780.

Hotelling, H. (1929). Stability in competition. Economic Journal, 39, 41-57.

Lach, S. (2002). Existence and persistence of price dispersion: An empirical analysis. The Review of Economics and Statistics, 84 (3), 433-444.

Midrigan, V. (2007). International price dispersion in statte-dependent pricing models. Journal of Monetary Economics, 55(8), 2231-2250.

O'Connell, P., \& Wei, S. J. (2002). The bigger they are, the harder they fall: Retail price differences across US cities. Journal of International Economics, 56, 21-53.

Parsley, D. C. (1996). Inflation and relative price variability in the short and long run: New evidence from the United States. Journal of Money, Credit and Bankingh, 28 (3), 323 341 .

Parsley, D. C., \& Wei, S. J. (1996). Convergence to the law of one price without trade barriers or currency fluctuation. The Quarterly Journal of Economics, 111 (4), 1211-1236. 
Parsley, D. C., \& Wei, S. J. (2001). Explaining the border effect: the role of exchange rate variability, shipping costs, and geography. Journal of International Economics, 55, 87 105.

Peterson, B., \& Shi, S. (2002). Money, price dispersion and welfare. Manuscript, Indiana University and University of Toronto.

Rauch, J. (1999). Networks vs. markets in international trade, Journal of International Economics, 48, 7-35.

Reinsdorf, M. (1994). New evidence on the relationship between inflation and price dispersion, American Economic Review, 84(3), 720-731.

Tommasi, M. (1994). The consequences of price instabilityon search markets: Toward understanding the effects of inflation. American Economic Review, 84(December), 1385-1396.

Tommasi, M. (1999). On high inflation and the allocation of the resources. Journal of Monetary Economics, 44(December), 401-421.

Tsurata, Y. (2008). What affects intranational price dispersion?: The case of Japanese gasoline prices. Japan and the World Economy, 20(4), 563-584.

Van Hoomissen, T. (1988). Price dispersion and inflation: Evidence from Israel. Journal of Political Economy, 96(6), 1303-1314. 